\title{
頸椎症，頸椎椎間板ヘルニアに対する手術法選択
}

\author{
井 須 豊 彦
}

\section{Surgical Selection for Cervical Spondylosis and Cervical Disc Hernia \\ by}

Toyohiko Isu, M.D.

from

Department of Neurosurgery, Kushiro Rousai Hospital

Surgical selections for cervical spondylosis and disc hernia are controversial. Cervical spondylosis and disc hernia can be approached either posteriorly or anteriorly. The author reviewed 480 patients who underwent the anterior approach and 61 patients who underwent the posterior approach for cervical spondylosis and disc hernia during the past 12 years.

Anterior cervical decompression seems to be the best approach because posterior spurs and disc hernias are located in the anterior spinal canal. The author thinks that cervical laminoplasty is indicated in patients with 4 or more levels of stenosis associated with calcification of yellow ligament. Anterior decompression and fusion is required in cases of kyphosis. To avoid doner site problems and concentrating stress at the adjacent levels of operated cervical spine, the author devises an anterior approach by vertebrodiscotomy or transvertebral approach, which permitted some movement at the operated disc level. My surgical procedure with poly-L-lactide screws allows early mobilization and does not require the application of an external fixator.

(Received September 11, 2001 ; accepted December 28, 2001)

Key words : cervical spondylosis, cervical disc hernia, surgical selection

Jpn J Neurosurg (Tokyo) $11: 453-460,2002$

\section{はじめに}

頸椎症，頸椎椎間板ヘルニアに対する手術アプローチ としては後方アプローチと前方アプローチがあるが，ど ちらのアプローチを選択するかに関しては議論のあると

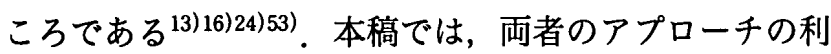
点, 問題点を述べるとともに，現在著者が行っている手 術アプローチの選択ならびに手術法を紹介する.

\section{手術アプローチの選択}

後方アプローチとしては古くから椎弓切除術が行われ てきたが，後方支持組織の破壊により後桸弯形が起こり 得ることが問題点として指摘されている。そののた，各 種の脊柱管拡大術が行われている ${ }^{12) 28)}$ 。最近では, 椎弓 形成のみならず，勒帯，筋肉等の後方支持組織を可能な かぎり温存しょうとする試みがなされてきている3754).

後方アプローチの適応は, 一般的には 3 椎間以上の病 変例や黄色鞄帯石灰化症合併例である ${ }^{13) 16(53)}$. 3 椎間以 上でも積極的に前方アプローチを好む術者 ${ }^{24) 25)}$ がいるが

釧路学災病院脳神経外科/F085-8533 釧路市中園町 13-23〔連絡先：井須豊彦〕

Address reprint requests to: Toyohiko Isu, M.D., Department of Neurosurgery, Kushiro Rousai Hospital, 13-23 Nakazono-cho, Kushiro-shi, Hokkaido 085-8533, Japan 
A

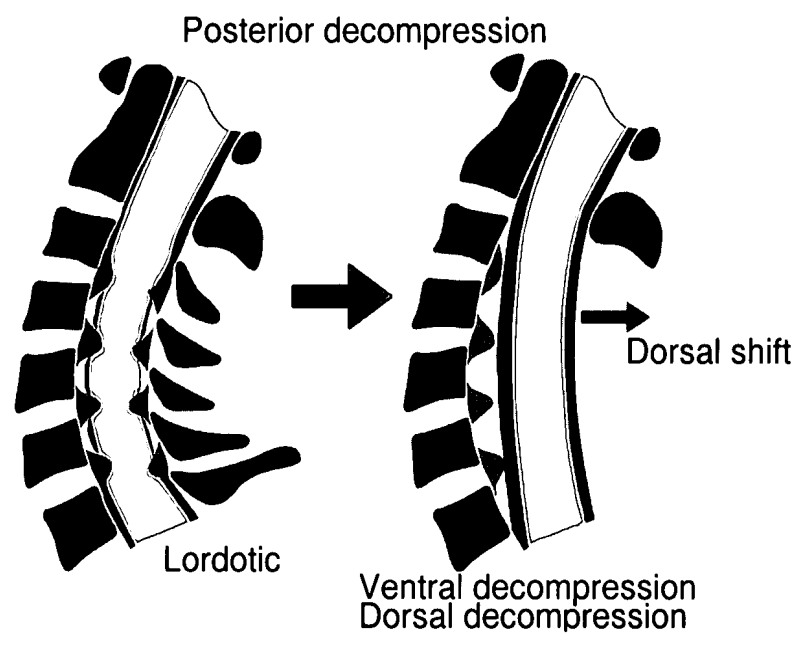

B

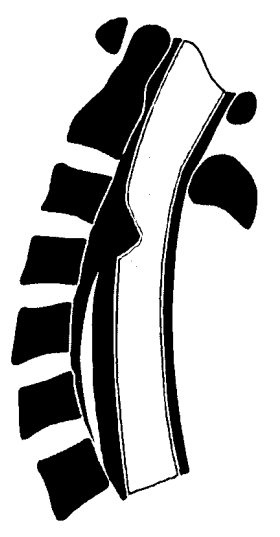

C

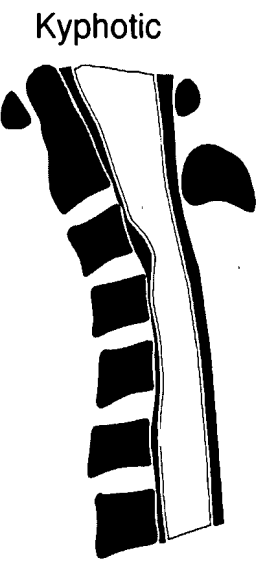

Fig. 1 A : Dorsal and ventral full decompression is possible by a dorsal shift of the spinal cord after a posterior approach.

B, C : Ventral decompression is insufficient in cases with localized massive lesions (B) or with kyphosis (C).

手術手技の難しさ，頸部運動制限等のため議論のあると ころである．脊柱管狭窄症を合併する場合には 2 椎間以 内であっても後方アプローチを行うとの報告もある が13)16)53)，著者は手術法選択に脊柱管狭窄症の有無を考 慮に入れていない. Kadoya $5^{25)}$, 中川ら ${ }^{33)}$ の報告では脊 柱管狭窄症が存在していても前方除圧術により良好な手 術結果が得られている．前方病変は前方より，後方病変 は後方よりアプローチすることは理にかなったことと思 われる。

後方アプローチの問題点を述べる，後方支持組織を温 存する脊柱管拡大術を用いても術後, 後彎変形を生じる 可能性がある．また, 術後に発生する C5, C6 神経根麻 㽻も無視できない合併症の一つである ${ }^{13)}$ ．里見ら ${ }^{40)} に よ$ れば, $7.8 \%$, Uematsu ら ${ }^{49}$ によれば $5.5 \%$ と報告されて いる.多くは回復するが社会復帰を遅らせる要因となる。 原因としては tethering effect, minor trauma, 神経根の 滅圧不足が報告されているが13), 原因不明のこともある. 手術手技の改善により発生頻度が少なくなっているとの 報告 ${ }^{40)}$ もあり，手術手技的要因が大きいと思われる，神 経根の減圧のために foraminotomy を行うとの報告 ${ }^{16)}$ が ある一方, foraminotomy は必要ではないとする報告40)も あり，議論のあるところである.

著者の考えでは, 顕微鏡下に foraminotomy を行い神経 根を十分に除圧することにより，術後に発生する C5 神 経根麻鼽の発生頻度を減らすことができると思われれ る. Fig. 1A に示したように, 後方アプローチは術後, 脊 髄が後方へ偏位することにより後方のみならず偹髄前方 の除仕も可能なアプローチである。しかしながら, 術前 より後彎形成がみられる場合（Fig. 1C）には前方除圧は
不十分となり, 後方アプローチの適応ではない(1)2)13)53). また，前方病変が著明な場合（Fig. 1B）にも前方除圧は 不十分となる ${ }^{1)}$. 後彎形成例に後方除圧術を行った症例 (Fig. 2)を示す. 術後 6 年目の MRI では後方除圧は良好 であるが，C3/4レベルにて前方から脊髄が圧排されてい る. 本症例に対しては, 頸椎前方用伸展型チタン製人工 椎体（商品名; $\mathrm{ADD}^{\circledR}$ ) ならびに頸椎前方プレート（商 品名; ATLANTIS $\left.{ }^{\circledR}\right)$ を用いて前方固定術を行った。術後, 症状は改善し後彎は消失した. 後方アプローチでは術後, 肩こり, 頸部痛を強く訴えることが多く, 長期間持続す る傾向がある. 近年, 筋肉, 勒带等の後方支持組織を可 能なかぎり温存する後方アプローチが行われているが避 けがたい合併症と思われる，術後にみられる肩こり, 頸

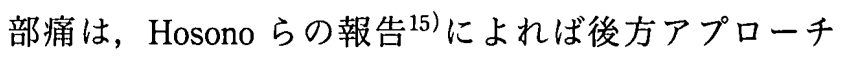
では $60 \%$, 前方アプローチでは $13 \%$ に認められており, 後方アプローチで明らかに発生頻度は高い傾向にある $(\mathrm{p}<0.05)$. 丸岩らの報告 ${ }^{32}$ でも neck pain は $28 \%$ に, shoulder painは33\%にみられている. 神経症状判定基準 に反映されていないが無視できない症状と思われる。著 者が後方アプローチを好まない理由の一つである.

前方アプローチでは軟部組織損傷, 脊髄神経根損傷, 移植骨ならびに移植骨採取部位に関する合併症が問題で ある ${ }^{46)}$. 軟部組織損傷としては種々の合併症が報告され ている，喉頭浮腫による気道狭窄5)を防ぐには，気管を 直接露出しないよう注意深い剝離を行い, 開公器にて長 時間，気管を圧迫しないことが重要である ${ }^{43)}$. 開空器の 位置を定時的に变え気管を間欠的に圧迫する. また術後 に発生する嗄声, 嚥下障害も無視できない合併症の一つ

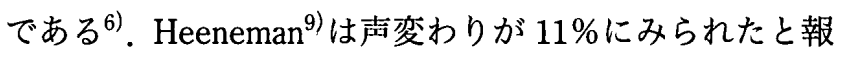



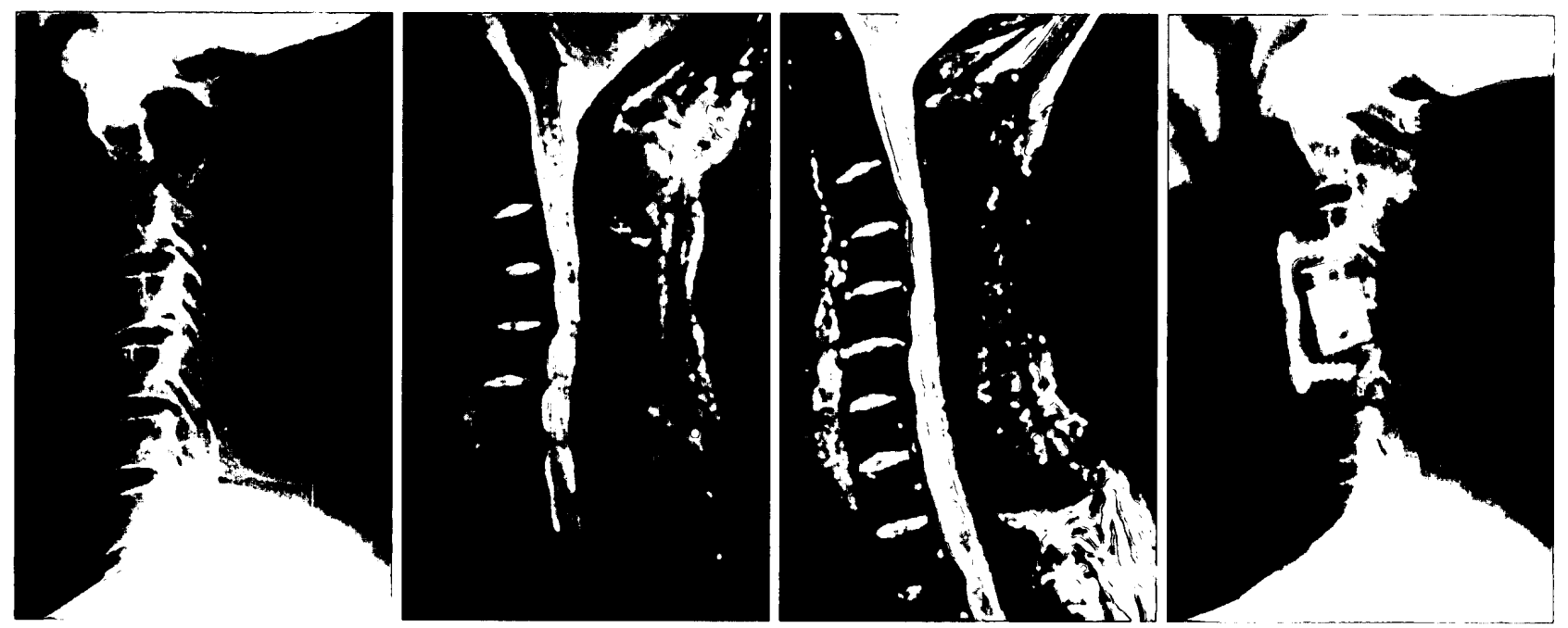

$\overline{\mathbf{A}|\mathbf{B}| \mathbf{C} \mid \mathbf{D}}$

Fig. 2 A : Preoperative cervical spine film shows kyphosis.

B : Preoperative MR image shows cord compression at C3/4, C4/5, and C5/6.

$\mathrm{C}$ : Postoperative MR image six years after cervical laminectomy shows ventral compression of the spinal cord at $\mathrm{C} 3 / 4$.

D : Postoperative cervical spine film after the anterior cervical fusion shows the improvement of the kyphotic curvature.

A 57-year-old man initially underwent a C3-C7 laminectomy for cervical spondylosis. Six years after the initial surgery he had a 3-month history of numbness and clumsiness in his upper extremities. An anterior corpectomy of $\mathrm{C} 4$ and a fusion of $\mathrm{C} 3-\mathrm{C} 5$ using an anterior distraction device and an anterior cervical spine plate was performed.

(He was operated on by Dr. Hida and Dr. Iwasaki)

告している，上甲状腺動脈，下甲状腺動脈付近では上喉 頭神経, 反回神経が隣接して走行しているため注意を要 する．顕微鏡下手術の発展により手術は安全になってい るが, 軟部組織損傷は無視できない合併症と思われる。 また，従来の手術法4)39) では，移植骨採取に伴う合併症 は避けられない到50)．これら合併症を避けるために種々 の手術法が開発されている811114)17 23)27)29)31133).

hydroxyapatite ${ }^{27) 29)}$ や自家椎体を用いる方法 ${ }^{18)}$ では, 術 野が広く神経の減圧は容易である。一方，最近行われて

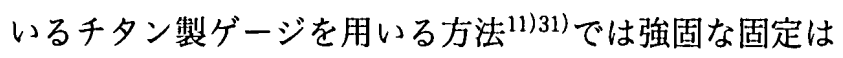
可能であるが, 術野が㹨く上記方法に比べて神経の減圧, 特に神経根の滅圧はしづらいと思われる．Fig. 3 に示し たように椎間板の上方に神経根が位置しているためであ る. 前方固定術では移植骨固定に伴う種々の問題点があ る. 移植骨の脱転, 偽関節形成の発生頻度を減らすため には臥床安静, 1〜2 力月間の頸部カラーによる外固定が 必要であり社会復帰を遅らせる要因となっている，特に 多椎間固定例では移植骨の脱転, 偽関節形成の発生頻度 は，1椎間に比べて高い傾向にある．前方プレートは転 移性脊椎腫晹や外傷例に対して頸椎の彎曲の維持, 矯正 ならびに移植骨脱転防止の目的で用いられている3338)44) が, 私自身の考えでは, 頸椎症に対する適応は慎重でな ければならないと考えている，通常，前方プレートとし
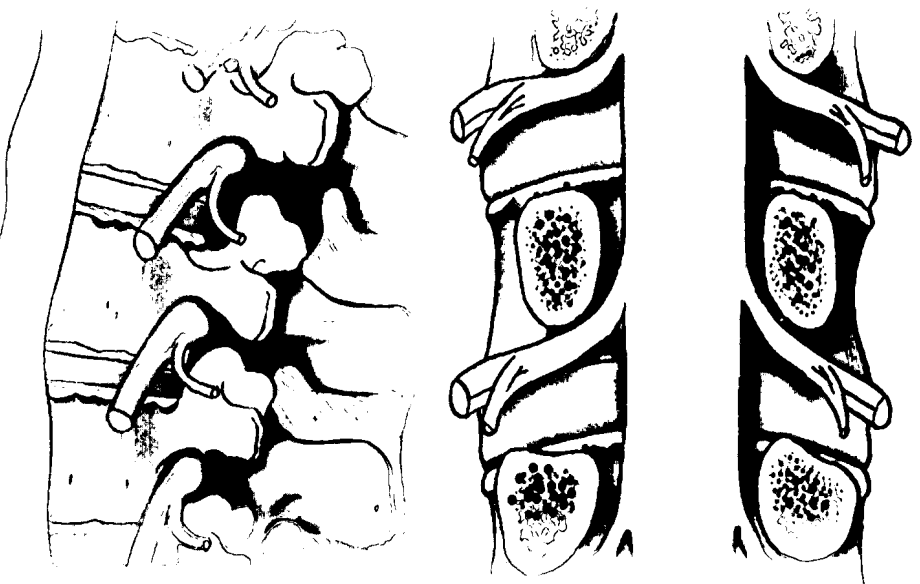

Fig. 3 Schema of the anatomical relationship between the nerve root and the intervertebral disc

てはチタンやステンレスが用いられているため骨瘜合後 も生体内に残存し，常に脱転，破損，感染の可能性があ

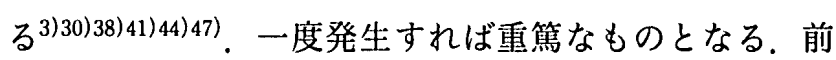
方プレートは再手術例, 後彎形成例等適応を絞り ${ }^{10)}$, 初 心者では経験豊かな術者に指導を受けるべき手術と思わ れる．Fig. 2 は後彎形成例に頸椎前方用伸展型チタン製 人工椎体 (商品名; $\mathrm{ADD}^{\circledR}$ ) ならびに頸椎前方プレート (商品名; ATLANTIS ${ }^{\circledR}$ ) を用いて前方固定術を行った症 
Table 1 Summary of the reports on postoperative stenotic changes at adjacent levels on MR images

\begin{tabular}{|c|c|c|c|}
\hline Authors & Year & Rate & Follow-up period \\
\hline Okamoto $^{36)}$ & 1991 & $20 \%$ & $3 \mathrm{Y} 11 \mathrm{M}$ \\
\hline Teramoto $^{45)}$ & 1994 & 71 & $10 \mathrm{Y}$ \\
\hline Toyama $^{48)}$ & 1997 & 60 & $20 \mathrm{Y}$ \\
\hline Isu & 2002 & 39 & $5 \mathrm{YMM}$ \\
\hline
\end{tabular}

$\mathrm{Y}:$ years $\mathrm{M}:$ months

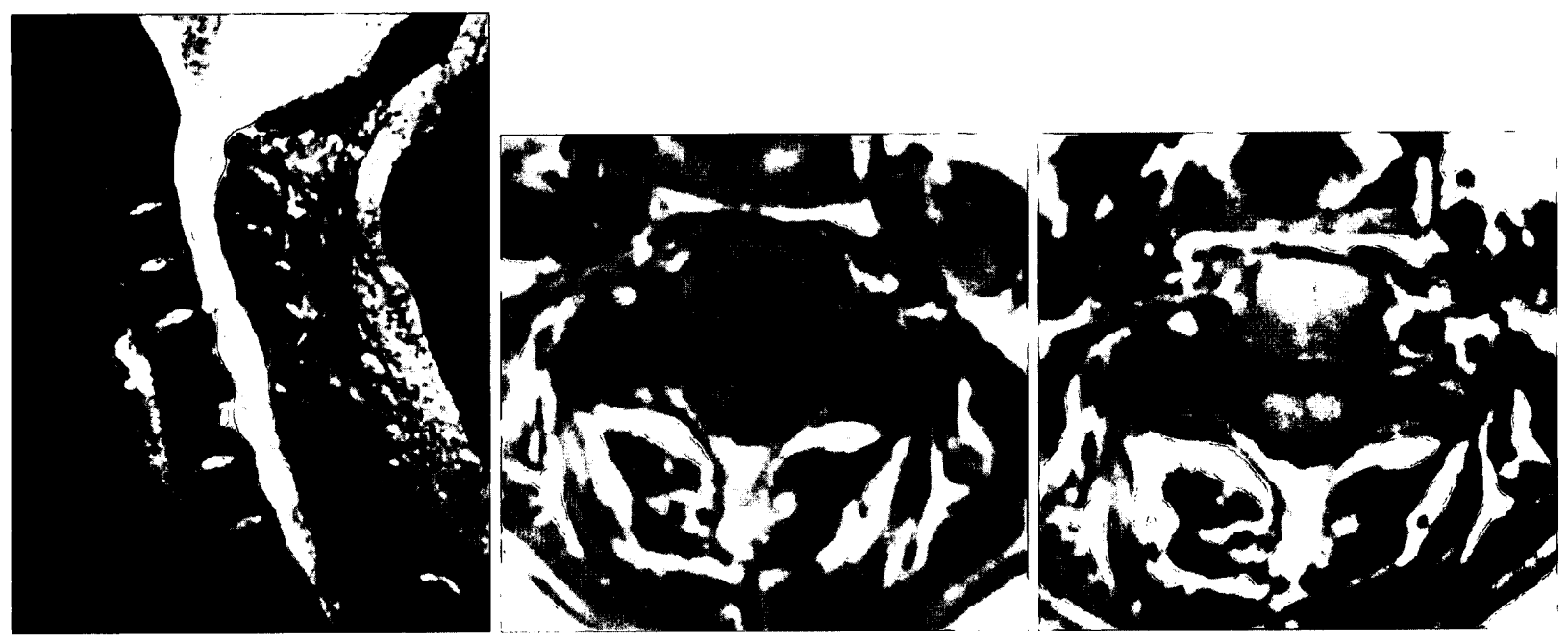

$\overline{\mathbf{A}|\mathbf{B}| \mathbf{C}} \quad$ Fig. $4 \quad$ A, B : MR images one year and eight months after the anterior fusion at $\mathrm{C} 5 / 6$ and $\mathrm{C} 6 / 7$ showed a disc herniation at $\mathrm{C} 4 / 5$ ( $\mathrm{A}:$ sagittal view, $\mathrm{B}:$ axial view : $\mathrm{C} 4 / 5)$.

$\mathrm{C}:$ MR image 3 months after anterior fusion revealed no disc herniation at $\mathrm{C} 4 / 5$.

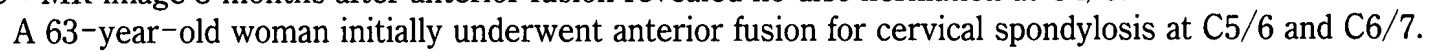
One year and six months after the anterior fusion she began to complain of numbness and weakness in both upper extremities, with the right being worse than the left. After that, she experienced a two month progression of gait disturbance. An anterior decompression at $\mathrm{C} 4 / 5$ was then performed.

例を示す．前方固定術では手術椎間が固定されるため首 の動きは悪くなる．特に 3 椎間以上では著明であり，日 常生活に不便を感じることがある，多椎間固定手術が好 まれない理由の一つである。頸椎前方固定術の問題点と しては術後, 固定隣接椎間に負荷が加わり変性変化が助 長されることである，そのため術後改善した神経症状が 再び悪化し再手術が施行されることがある726)34445). MRI 上の変化は Table 1 に示したように, 術後平均 20 年 の経過観察例を示す戸山らの報告 ${ }^{48)}$ では $60 \%$ と報告さ れている.われわれの検討でも $39 \%$ に変化がみられてい る. しかしながら, 実際に神経症状が再発し再手術に至 る頻度は少ないと思われる. Table 2 に過去の報告 例7) 26)34) 45) を示す，角家の報告 ${ }^{26)}$ では，発生頻度は $5 \%$ であるが, 術後平均 10 年以上の報告では発生頻度は高 くなっている ${ }^{2634) 45)}$ ，最近では，長期経過観察が可能と なってきているため, 発生頻度は今後, 徐々に増加して いくものと思われる. Fig. 4 に前方除圧固定術後に手術
隣接椎間にヘルニアが出現し再手術を行った症例を示 す。前方固定術の隣接椎間に対する悪影響は宿命的なも のといえる，それゅえ，脊柱が本来もっている生理的可 動性を温存する手術は固定隣接椎間に対する負荷を軽減 し, 前方固定術の欠点を補う手術法として注目すべきも のと思われる。

\section{著者自身の手術法選択ならびに手術法の変遷}

病変部が前方に存在するため, 前方アプローチにより 病変部を摘出する前方除圧術を第一選択として行ってい る. 後方アプローチは 4 椎間以上の病変, 黄色勒帯石灰 化症の合併例のみに施行しているため，後方アプローチ が選択される頻度は低くなつている。著者は手術法選択 に脊柱管狭窄症の有無を考慮に入れていない，過去 12 年間に手術が施行された 541 例中, 前方除圧術を 480 例 に, 後方除圧術を 61 例に行った. 後方除王術の術式と 

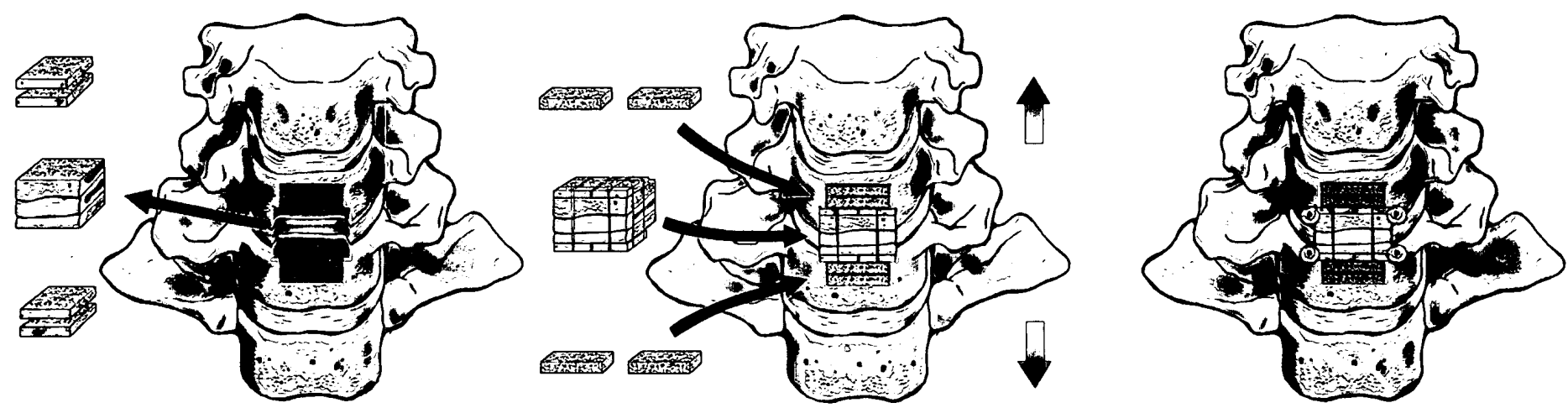

$\underline{\mathbf{A}|\mathbf{B}| \mathbf{C}}$

Fig. 5 Schemas of anterior decompression by vertebrodiscotomy

A : The disc body unit and the bone of the vertebral body is removed.

B, C : After decompression, the disc body unit is inserted and fixed with poly-L-lactide screws.
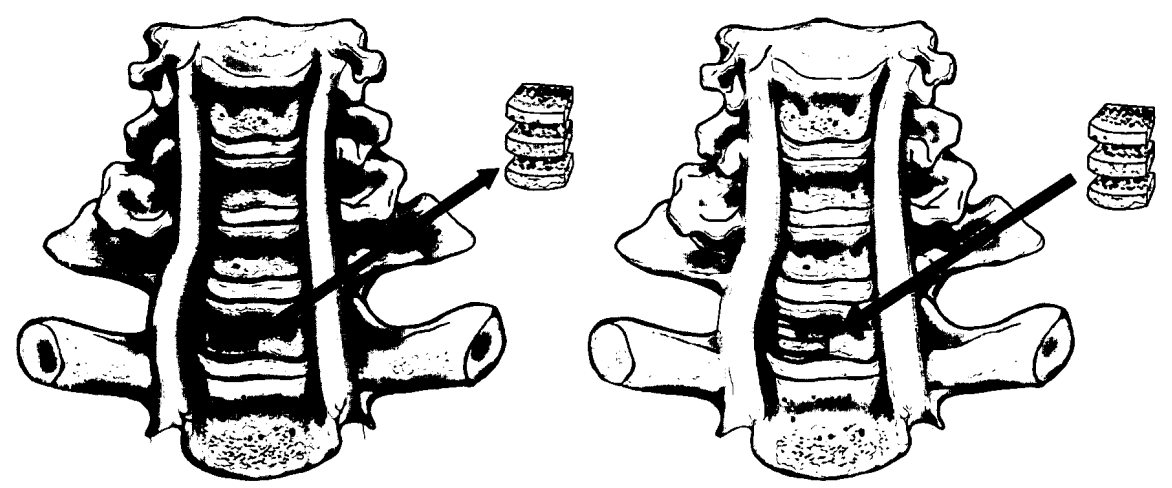

$\underline{\text { A|B }}$ Fig. 6 Schemas of anterior decompression for lateral disc hernia or lateral spur by transvertebral approach

A : The bone of the vertebral body on the right side is removed by Williams spinal saw.

B : Herniotomy is done through the bone defect of the vertebral body, which is approximately $8 \mathrm{~mm}$ in diameter. After decompression, the bone grafts are inserted.

しては当初は椎弓切除術を行ってきたが, 最近では棘上, 棘間勒帯等の後方支持組織を温存する(片側アプローチ) 術式を採用している。

従来より行われてきた Smith-Robinson 法年) や Cloward 法4)では腸骨採取に伴う合併症は避けられず46)50)，早 期離床の妨げとなっている。著者は 1990 年より腸骨採 取に伴う合併症を避けるため自家椎体を用いた頸椎前方 除圧固定術を採用し良好な手術成績をあげてきた ${ }^{18)}$ 。し かしながら，前述したように頸椎前方除圧固定術では固 定隣接椎間に対する負荷は避けられない。 そのため, 1993 年より手術隣接椎間に対する負荷を軽減する目的 で手術椎間の可動性を温存する手術, 椎間板還納術を開 発し行っている ${ }^{19 \sim 23)}$. 手術 (Fig. 5) ${ }^{23)}$ は spinal saw を用 いて椎体, 椎間板ユニットを一塊として摘出。減圧後, 椎体椎間板ユニットを再抻入し生体内分解吸収性スク リューにて脱転防止を行うものである ${ }^{52)}$. 本法では手術 隣接椎間に対する負荷が軽減し手術隣接椎間の変性・変
Table 3 Follow-up study of postoperative stenotic change at adjacent levels on MR images in anterior fusion and vertebrodiscotomy

\begin{tabular}{crr}
\hline Follow-up term & \multicolumn{1}{c}{ Anterior fusion } & Vertebrodiscotomy \\
\hline$\sim 1$ (years) & $4 / 108(4 \%)$ & $7 / 135(5 \%)$ \\
$\sim 2$ & $16 / 108(15)$ & $13 / 135(10)$ \\
$\sim 3$ & $18 / 100(18)$ & $11 / 91(12)$ \\
$\sim 4$ & $22 / 91(24)$ & $6 / 56(11)$ \\
$\sim 5$ & $22 / 72(31)$ & $3 / 29(10)$ \\
$\sim 6$ & $17 / 54(31)$ & $2 / 10(20)$ \\
$\sim 7$ & $16 / 41(39)$ & $1 / 8(13)$ \\
$\sim 8$ & $14 / 35(40)$ & $0 / 1$ \\
$\sim 9$ & $8 / 18(44)$ & \\
$\sim 10$ & $2 / 5(40)$ & \\
\hline
\end{tabular}

Postoperative stenotic change was examined by MR gradient echo image. 
Table 4 Summary of the anterior approach used during the past 12 years in the department of neurosurgery, Kushiro Rosai Hospital

\begin{tabular}{|c|c|}
\hline Anterior approach & No. of cases \\
\hline $\begin{array}{l}\text { Fusion using bone grafts obtained } \\
\text { from vertebral bodies }(\mathrm{F})\end{array}$ & 174 \\
\hline Vertebrodiscotomy $(\mathrm{V})$ & 162 \\
\hline Transvertebral approach $(\mathrm{T})$ & 72 \\
\hline$V+T$ & 34 \\
\hline $\mathrm{F}+\mathrm{V}$ & 28 \\
\hline Other procedures & 10 \\
\hline Total & 480 \\
\hline
\end{tabular}

化に起因する神経症状悪化，再手術の発生頻度は減少す るものと思われる．実際われわれの検討結果では，手術 隣接椎間の MRI 上の変化, 隣接椎間に起因する再手術の 頻度は前方固定術例に比べて低い傾向にあった．MRI gradient echo 像により手術隣接椎間の狭窄性変化につい て，自家椎体使用による前方除圧固定術 108 例と椎間板 還納術 135 例で比較検討を行つた (Table 3). 術後経過観 察期間は前方除圧固定術例では平均 6 年 4 力月（1 年〜 10 年 5 力月), 椎間板還納術例では平均 3 年 2 力月 ( 1 年 7 年 5 力月）である，MRI 上の変化は，前方除圧固定術 例では 108 例中 42 例（39\%）に認められたが，椎間板 還納術例では 135 例中 18 例（13\%）にみられるのみで あった。 また再手術は，前方除圧固定術例では $4 \% に$, 椎間板還納術例では $1 \%$ に行われた。本法の問題点は手 技がやや複雑であり，特殊な手術器具（Williams spinal saw）を必要とすることである．またわれわれの検討で は, 手術椎間の可動性が約 50\%ほど減少し, 約 15\%の症 例で可動性の消失がみられている，手術椎間の可動性を 温存する手術法としてはいまだ完全な手術法とはいえな い. 最近, 著者は, 手術椎間の可動性を可能な限り温存 できる手術法として経椎体アプローチ法を行っている35) 42)51)。本手術法は神経根症に対して開発された手術法で ある. Fig. 3 に示したように椎間板の上方に神経根が位 置しているため, 椎体経由では椎間板経由に比べて神経 根に対する到達距離が短く神経根の除圧が容易であり椎 間板を温存できる利点を有している，経椎体アプローチ 法では頸部カラー等の頸部外固定を必要としないことも 利点の一つである．われわれが行っている手術法を紹介 する（Fig. 6)。手術椎間の上位椎体に spinal saw を用い て, 幅 $8 \mathrm{~mm}$, 厚さ $8 \mathrm{~mm}$ 程度の骨空を作成し神経根を 王迫しているへルニア, 後方骨棘を除去する. 滅圧後, 骨空内へ骨片を再挿入して手術を終了する，著者は脊䯣 症を呈する頸椎症, 頸椎椎間板へルニア例に対しても本
手術法の適応があると考えて行っているが今後の検討が 必要と思われる。

過去 12 年間に施行された頸椎前方除圧術の内訳を Table 4 に示す. 自家椎体を用いた前方除圧固定術より椎 間板還納術, 経椎体アプローチ法へと手術法は変遷して いる，手術法の変更の理由は前述のとおりである．頸椎 症, 頸椎椎間板へルニアに対する手術法の選択に際して は各手術法の利点, 欠点を理解したうえで選択すべきだ と思われる．患者に満足してもらえる手術を行うべきで ある。特に，脊椎手術を始められたばかりの医師は，流 行している手術法を安易に選択すべきではなく，重鹳な 合併症をきたす可能性のある手術は避けるべきと思われ る.

本稿の一部は, 第 21 回日本脳神経外科コングレス (2001, 山形) プレナリーセッションにて発表した.

\section{文 献}

1）会田育男, 林浩一郎, 和田野安良, 原田 繁, 平林宏之, 中島 宏, 中川 司, 矢吹 武: 頸部脊柱管挔大術の限 界一再手術例の検討。整形外科 $47: 17-21,1996$.

2) Batzdorf U, Batzdorf A: Analysis of cervical spine curvature in patients with cervical spondylosis. Neurosurgery 22: 827-836, 1988.

3) Casper W, Barbier DD, Klara PM : Anterior cervical fusion and Casper plate stabilization for cervical trauma. Neurosurgery $25: 491-502,1989$.

4) Cloward RB: The anterior approach for removal of ruptured cervical disks. J Neurosurg 15:602-617, 1958.

5) Emery SE, Smith MD, Bohlman HH: Upper-airway obstruction after multilevel cervical corpectomy for myelopathy. J Bone Joint Surg 73A : 544-551, 1991.

6) Flynn TB: Neurologic complications of anterior cervical interbody fusion. Spine 7:536-539, 1982.

7) Gore DR, Sepic SB: Anterior discectomy and fusion for painful cervical disc disease. Spine 23: 2047-2051, 1998.

8) Hankinson HL, Wilson $\mathrm{CB}$ : Use of the operating microscope in anterior cervical discectomy without fusion. $J$ Neurosurg 43: 452-456, 1975.

9) Heeneman $\mathrm{H}$ : Vocal cord paralysis following approaches to the anterior cervical spine. Laryngoscope 83:17-21, 1973.

10) Herman JM, Sonntag VKH : Cervical corpectomy and plate fixation for postlaminectomy kyphosis. J Neurosurg $\mathbf{8 0}$ : 963-970, 1994.

11）飛騨一利, 岩㠃喜信, 阿部 弘: 頸部脊椎症に対するチ タン製ケージ 1 年以上上使用の経過锶察。脊椎脊随 13 ： $47-50,2000$

12）平林 冽：頸髄症に対する後方除圧法としての片開き式 頸部脊柱管抬大術について。手術 32:1159-1163, 1978.

13）平林 洌：頸椎症性脊髄症治療の進歩と課題. 日脊会誌 $11: 409-418,2000$.

14) Hirsh C: Cervical disc rupture: Diagnosis and therapy. Acta Orthop Scand 30:172-186, 1960. 
15) Hosono $\mathrm{N}$, Yonenobu $\mathrm{K}$, Ono $\mathrm{K}$ : Neck and shoulder pain after laminoplasty: A noticeable complication. Spine 21: 1969-1973, 1996.

16）伊藤達雄：春椎症，変性脊柱管狭窄症，伊藤達雄，服部 孝道, 山浦 晶編: 臨床脊椎凑蹎医学, 東京, 三輪書店, 1996, pp. 244-258.

17）井須豊彦, 阿部 弘, 岩崎喜信, 三森研自, 都留美都雄, 斎藤久寿, 小岩光行：頸部椎間障害における anterior discectomy without fusion の経験. Neurol Med Chir (Tokyo) 26: 481-486, 1986.

18) Isu $T$, Kamada $K$, Kobayashi $N$, Mabuchi $S$ : The surgical technique of anterior cervical fusion using bone grafts obtained from cervical vertebral bodies.J Neurosurg $\mathbf{8 0}$ : 16-19, 1994.

19）井須豊彦, 㝨島 瞈, 竹田 誠, 竹林誠治, 関 俊隆: 頸椎椎間板障害例に対する頸椎前方除王術の新しい試み 一頸椎前方除圧後の自家椎体, 椎間板 unit の移植術. 脳 外 24:823-827, 1996 .

20）井須豊彦，譬島 聡，関 俊隆，竹田 誠，竹林誠治： 頸椎椎間板障害例に対する頸椎前方除圧後の自家椎体, 椎間板 unit の移植術一術後放射線学的所見. Spinal Surgery 11:75-80, 1997.

21) Isu $T$, Minoshima $S$, Takeda $M$, Seki $T$, Fujiwara $S$, Takebayashi S: A surgical technique for a vertebral column autograft using the intervertebral disc for cervical disc disease. Acta Neurochir (Wien) 140:267-273, 1998.

22）井須豊彦：頸椎症・頸椎椎間板ヘルニア・頸椎後縦勒带 骨化症一生体内分解性スクリュー（ポリ-L-乳酸スク リュー）を用いた頸椎椎間板還納術. 高倉公明, 斎藤 勇, 佐藤 潔編: 図説脳神経外科 7, 泰咀一機能・解剖 · 手術. 東京, メジカルビュ一社，1999, pp. 78-83.

23）井須豊彦, 藤原昌治: 頸椎椎間板障害, 頸椎後縦勒带骨 化症に対する頸椎椎間板還納術。脊椎・脊髄神経手術手 技 $2: 5-9,2000$.

24）岩崎喜信，飛駱一利，阿部 弘，秋野 実：頸部脊椎症 の長期予後一術後 3 年以上の経過観察例の検討. Spinal Surgery 6:7-14, 1992.

25) Kadoya S, Nakamura T, Kwak R, Hirose G: Anterior osteophytectomy for cervical spondylotic myelopathy in developmentally narrow canal. J Neurosurg 63: 845-850, 1985.

26）角家 暁: 頸部脊椎症, 脳神経外科疾患の手術と適応 I . 東京, 朝倉書店, 1990, pp. 554-582.

27) Kim $P$, Wakai $S$, Matsuo $S$, Moriyama T, Kirino $T$ : Bisegmental cervical interbody fusion using hydroxyapatite implants : Surgical results and long term observation in 70 cases. J Neurosurg 88:21-27, 1998.

28）黑川高秀, 津山直一; 田中弘美, 小林正之, 町田秀人, 中村耕造, 飯塚 正, 星野雄一：棘突起縦割法頸椎脊柱 管挔大術。別冊整形外科 $2: 234-240,1982$.

29) Koyama $T$, Handa $J$ : Porous hydroxyapatite ceramics for use in neurosurgical practice. Surg Neurol 25:71-73, 1986.

30) Kostuik JP, Connolly PJ, Esses SI, Suh P: Anterior cervical plate fixation with the titanium hollow screw plate system. Spine 18: 1273-1278, 1993.

31) Matge $G$ : Anterior interbody fusion with the BAK-cage in cervical spondylosis. Acta Neurochir (Wien) 140:1-8, 1998.

32）丸岩博文, 千葉一裕, 渡辺雅彦, 松本守雄, 藤村祥一, 平林 洌，戸山芳昭：頸椎症性脊髄症に対する片開き式 脊柱管拡大術の長期成績。臨整外 35:411-416，2000.

33）中川 洋, 山田晃弘, 杉山忠光, 水野順一, 星野大作,
岩田金次郎：脊椎管狭窄を伴う頸椎椎間板疾患における microsurgical anterior approach. 脊髄外科 $1: 21-27$, 1987.

34）中間秀雄, 星野雄一, 吉川一郎, 大上仁志, 山口 修, 中村 仁: 頸椎前方固定術後の隣接椎間の変化一術後 5 年以上経過例の成績と問題点. 整形外科 48:15731576, 1997.

35）野口耕司，松下 睦：頸椎症に対する顕微鏡下経椎体前 方除王術の試み。別冊整形外科 13:54-57，1988.

36）岡本昭彦，四宮謙一，吉田裕俊，武滕直子，古屋光太郎, 山浦伊梁吉：頸髄症前方法術後症例における固定上下椎 間での脊咀圧迫一MRI 像の検討。整形外科 42:14811484, 1991.

37）大島義彦, 佐藤 浩, 林 雅弘, 横田 実, 平本典利： 脊柱管拡大術一片側侵入，有茎棘突起形成片開き法。脊 椎脊髄 $4: 577-583,1991$.

38) Randle MJ, Wolf A, Levi L, Rigamonti D, Mirvis S, Robinson W, Bellis E, Greenberg J, Salcman M: The use of anterior Casper plate fixation in acute cervical spine injury. Surg Neurol 36:181-189, 1991.

39) Robinson RA, Smith GW: Anterolateral cervical disc removal and interbody fusion for cervical syndrome. Bull Johns Hopkins Hosp 96:223-224, 1955.

40）里見和彦，平林 洌，市村正一，戸山芳昭，杉原繁明， 小川 潤，石井良章：頸部脊置症に対する片開き式椎弓 形成術の合併症と長期成績. 整形外科 $50: 317-323$, 1999.

41) Seifert V, Stolke D: Multisegmental cervical spondylosis: Treatment by spodylectomy, microsurgical decompression, and ostheosynthesis. Neurosurgery 29:498-503, 1991.

42）関 俊隆, 井須豊彦, 竹田 誠, 藤原昌治: Williams microsurgical saw を用いた経椎体アプローチ. Video Journal of Japan Neurosurgery Vol. 7, No. 2, 1999.

43）関 俊隆, 井須豊彦, 竹田 誠, 䒾島 聡, 矢野俊介: 頸椎椎間板障害に対する前方到達法の外科解剖.Video Journal of Japan Neurosurgery Vol. 8, No. 1，2000.

44) Shoung HM, Lee LS: Anterior metal plate fixation in the treatment of unstable lower cervical spine injuries. Acta Neurochir (Wien) 98:55-59, 1989.

45) Teramoto $T$, Ohmori $K$, Takatsu $T$, Inoue $H$, Ishida $Y$, Suzuki $\mathrm{K}$ : Long-term results of the anterior cervical spondylodesis. Neurosurgery 35: 64-68, 1994.

46) Tew JM Jr, Mayfield FH: Complications of surgery of the anterior cervical spine. Clin Neurosurg 23:424-434, 1976.

47) Tippets RH, Apfelbaum RI : Anterior cervical fusion with the Casper instrumentation system. Neurosurgery 22: 1008-1013, 1988.

48）戸山䓅昭, 平林 尚, 平林 洌, 里見和彦: 頸椎症性脊 髄症に対する前方除圧固定術の長期成績. MB Orthop 10: 117-125, 1997.

49) Uematsu Y, Tokuhashi $Y$, Matsuzaki H: Radiculopathy after laminoplasty of the cervical spine. Spine $23: 2057-$ 2062, 1998.

50) Whitecloud TS : Complications of anterior cervical fusion. Instr Cour Lect 27 : 223-227, 1978.

51）山田博是, 山本英輝, 中島克昌, 中島正光: 経椎体アプ ローチによる頸椎椎間板切除術. Spinal Surgery 10: 54-59, 1996.

52) Yamamuro T, Matsusue Y, Uchida A, Shimada K, Shinozaki $\mathrm{E}$, Kitaoka $\mathrm{K}$ : Bioabsorbable osteosynthetic implants of ultra high strength poly-L-lactide. Int Orthop (SICOT) 
18: 332-340, 1994.

53）米延策雄，和田英路：頸椎症性脊髄症，日脊会誌 10 ： 293-307, 1999.

54) Yoshida M, Otani K, Shibasaki K, Ueda S: Expansive laminoplasty with reattachment of spinous process and extensor musculature for cervical myelopathy. Spine 17: 491-497, 1992.

要

頸椎症，頸椎椎間板ヘルニアに対する手術法選択

井須 豊彦

頸椎症，頸椎椎間板へルニアに対する手術法選択に関しては議論のあるところである. 従来より行 われてきた前方除圧固定術では腸骨採取に伴う合併症がみられ，多椎間病変に適応がなく，固定隣接 椎間に起因する再手術がみられることなどが問題点として指摘されている.

著者は前方除圧術を第一選択として行ってるが，4 椎間以上の病变，黄色勒帯石灰化症の合併例に 対しては後方アプローチを選択している. 著者が前方アプローチとして採用している生体内分解吸収 性スクリュー(ポリーし-乳酸) を用いた椎間板還納術や経椎体アプローチ法では手術椎間の可動性が 温存されるため, 手術隣接椎間に起因する再手術の発生頻度が減少する可能性があり，今後の検討が 必要である. また本法では，頸部カラー等による頸部の外固定が必要ではない.

\section{脳神経外科ジャーナル}

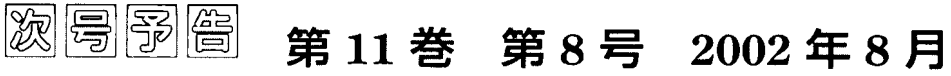

\section{䋨 説}

グリオーマの遺伝子治療 名古屋大学 若林 俊彦, 他

原 著

手術に必要な検查法一術中検查一 東京女子医科大学 伊関 洋, 他 手術手技・周術期管理

グリオーマの手術 山形大学 佐藤 慎掝, 他

\section{症例報告}

頸部痛発作の垃日，クモ膜下出血をきたした椎骨動脈解離性動脈瘤の 1 例 ·齊藤記念病院 小山 新弥, 他 ガンマナイフ治療後, 慢性硬膜下血腫を生じた聴神経腫瘍の 1 例 鳥取大学 庄 敦子, 他 悪急性に血腫の増大した海綿状血管腫の 1 例 平塚市民病院 宮崎 宏道, 他

進行性に MIB-1 index の上昇を示した papillary meningioma の 1 例 .神戸大学 森下 䁳二, 他 腫瘍の一部が悪性転化したと考えられる大脳鎌䯙膜腫の 1 例 .野江病院 河野 勝彦, 他 